\title{
$\equiv$
}

\section{Ownership Structure of Cooperatives as an Environmental Buffer*}

\section{Manuel Núñez-Nickel and José Moyano-Fuentes}

Carlos III University, Madrid; University of Jaén, Spain

\begin{abstract}
In this paper, we propose that the ownership structure in the cooperative form acts as an environmental buffer. It is a mechanism to obtain stronger linkages with suppliers by internalizing them, and in this way, obtaining fundamental resources. Using this strategy, the cooperative form can isolate itself from adverse environments and from competition from other organizational forms. Although cooperatives have higher survival probability in any economic context, in rival ideological environments they have less support than other organizational forms. To test these ideas, we have chosen data from the Spanish olive oil milling industry for 1944-98. During this period, Spain changed from a dictatorial to a democratic regime and from a self-subsistence economy in the post civil-war period to a broad liberal international economy. The results show that, whereas other organizational forms are affected by economic and ideological influences, the cooperative form isolates itself by changing the competition level.
\end{abstract}

\section{INTRODUCTION}

Within the research on the cooperative form, there remains a question the answer to which is not resolved: Does a cooperative's unusual ownership and governance structure give it any advantage over its commercial rivals? To respond to this question is difficult because organizational forms pursue different targets (Pencavel, 2002). Consequently, their performance criteria for measuring success are also different (Rothschild and Whitt, 1989, pp. 160-1). Depending on the characteristics studied, authors reach completely opposed conclusions. There exist situations where the cooperative form could be dominated by the capitalist form (Ben-ner and Jones, 1995; Putterman, 1982), or where the cooperative form is as sturdy as the capitalist form (Ben-ner, 1988). However, there also exist factors that could favour the cooperative form (Bonin et al., 1993; Russell, 1985).

Address for reprints: Manuel Núñez-Nickel, Department of Business Administration, C/ Madrid, 126, E-28903 Getafe (Madrid), Spain (mnunez@emp.uc3m.es).

This is the pre-peer-reviewed version of the following article: 
These factors include its fundamental characteristic, organizational democracy, which generates incentives and motivation among workers inside the organization (Simons and Ingram, 2000). However, democracy could be harmful when the ideology of the environment is opposed to it (Simons and Ingram, 1997). Moreover, democracy is the opposite of a hierarchy or strategic leadership in which the fundamental organizational characteristic is the drive to obtain efficiency (Williamson, 1987). In the empirical arena, results are not conclusive when cooperative productivity is compared with ordinary capitalist firms (Bonin et al., 1993).

In summary, a systematic study that controls for firm size, industry, and internal structure is fundamental before we can specify which organizational type is preferable in relation to its performance: the cooperative form or other capitalist forms (Rothschild and Whitt, 1989, p. 167).

To our knowledge, there are only three systematic studies that compare cooperatives with other organizational forms in relation to their organizational performance, controlling by internal structure, industry and environment: Barnett and Carroll (1987), Rao and Neilsen (1992), and Barron et al. (1998). Rao and Neilsen's paper (1992) is the only work that specifies an internal characteristic as the reason why stock companies are less vulnerable: agency costs. The other two studies describe the interrelationships between both populations but through influences external to the organization.

In this paper, we follow the same tradition as these three papers, and try to respond to the question proposed by Barron et al. (1998, p. 28): 'Does the cooperatives' [credit unions] unusual ownership and governance structure give them any advantages over their commercial rivals?'. To respond to this question, we examine whether different ownership structures (cooperative versus other organizational forms) could translate into advantages or disadvantages for survival when they compete with each other and face different economic or ideological environments. We propose a different explanation that leads to results opposed to those in Rao and Neilsen's paper (1992) but fully ratifies the finding reached in Barron et al.'s paper (1998), namely, that cooperatives are advantageous because they use the ownership structure as a mechanism to obtain fundamental resources from the environment. This crucial advantage allows them to isolate themselves from the environment and act as predators in the face of competition from other organizational forms.

This finding is supported by results obtained from the population of Spanish olive oil mills ('almazaras' in Spanish) for 1944-98. During this period, Spain suffered radical economic and political changes that provide environmental variability in which to test the robustness of the interrelations between the cooperative form and other ordinary capitalist forms.

The structure of the paper is as follows: firstly, we present the description of the olive oil milling industry and the political and economic conditions pertaining during this historical period in Spain; secondly, we develop the theoretical back-

This is the pre-peer-reviewed version of the following article: Journal of Management Studies, vol.41, n.7, p.1131-1152, which has been published in final form at http://dx.doi.org/10.1111/j.1467-6486.2004.00469.x 
ground; thirdly, we describe the research design, and show the results; and finally, we conclude with our thoughts with respect to the findings.

\section{OLIVE OIL MILLING INDUSTRY AND SPANISH POLITICAL AND ECONOMIC ENVIRONMENT}

\section{Industry Structure}

The activity of oil mills ('almazaras' in Spanish) is centred on extraction, marketing and storage of virgin olive oil. During the study period, marketing was undertaken through middlemen, and was given little importance as an internal organizational activity. Only now, these organizations are becoming aware of the advantages to be gained by making this an internal activity (Ernst \& Young Assessors, 1992, p. 175). Storage is a necessary activity, but does not entail a great consumption of either human or material resources, and can be considered an irrelevant activity. Therefore, the extraction stage is the fundamental activity of an oil mill, and the differences between the mills are determined by their internal characteristics (such as extraction technology, power installed, number of employees, or milling capacity).

The significance of the extraction stage implies that the olive (the sole raw material) is the critical resource, or the niche in which the oil mills operate. No other relevant resource can be found. A specialized work force is not required. Customers act in a monopoly regimen and release the olive oil onto the final market. However, we might assume that the production level is independent of customer demand because of the intervention of the Spanish State. The oil mills have a guarantee to sell all their production at a minimum price (paid by the State). This has contributed to a lack of orientation to the market in these firms (Torres, 1998).

\section{Cooperatives Versus Other Organizational Forms}

As in other industry sectors, the ownership and governance structure might be chosen to distinguish two organizational forms, the cooperative form and other capitalist forms (Barnett and Carroll, 1987; Barron et al., 1998; Ranger-Moore et al., 1991; Rao and Neilsen, 1992). The former is constituted as a democratic organization, and its management is based on the principle of one member, one vote. The other organizational forms (capitalist forms) have the characteristic that the number of votes is directly linked to the size of shareholding (Barron, 1995, p. 138).

Cooperatives in this industry are typical of agricultural cooperatives (Hansmann, 2000, pp. 120-45). Similar to cheese, canning, or fruit-juice factories, they not only take possession of their members' commodities (olives) but also process them into finished product (olive oil). Their members are private small olive

This is the pre-peer-reviewed version of the following article: Journal of Management Studies, vol.41, n.7, p.1131-1152, 


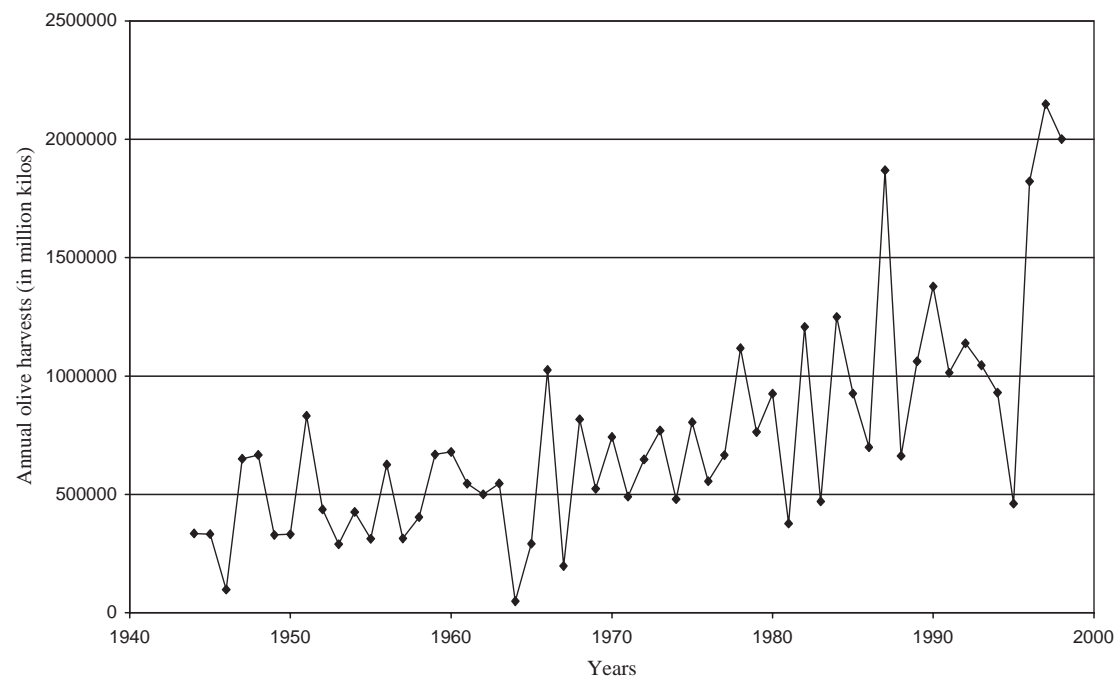

Figure 1. Evolution of the annual olive harvests 1944-1998

farmers who contribute with their own crops. In this way, they are closer to Israeli moshavim than to kibbutzim (Simons and Ingram, 2000, p. 62) or to Hungarian agricultural cooperatives (Carroll et al., 1988).

\section{Environmental Variability in Spain}

The biological nature of olives as a resource means large year-to-year fluctuations (Figure 1) and its transformation process depends on a biological system involving many factors that are difficult to predict and control, such as climate and diseases. Moreover, olive trees are a long-time investment because they take many years to grow before they become productive. These aspects, together with the rapid deterioration of olives from the moment they are harvested, create uncertainty in this sector. However, farmers in Spain cannot eliminate it because of the lack of a futures market and the strategic disadvantage of forward contracts because of the monopsony situation.

The environment in Spain has undergone several stages, both political and economical, that run from an absolute precariousness to a relatively stable and advanced situation.

General Franco, after a military coup and subsequent civil war, overthrew the constitutional government in 1939. The consequence was a military dictatorship, which stood until 1975. During this period, two clear economic stages may be identified: (1) a self-subsistence economy distinguished by a post-war economic depression and the international isolation of fascist regimes by western democracies when they won the Second World War; and (2) incipient economic devel-

This is the pre-peer-reviewed version of the following article: Journal of Management Studies, vol.41, n.7, p.1131-1152, 
opment after the USA recognized the Franco regime in 1960, leading to western democracies removing economic isolation (Tortella, 1994, p. 204).

In relation to cooperatives, Spain has other paradoxes, such as the network of the workers' cooperatives of Mondragon (Gutierrez-Johnson and Whyte, 1977). However, the relationship of Franco and the cooperatives was always hard (Rothschild and Whitt, 1989, p. 170). Franco was worried more about ideological deviation than economic solutions (Marí-Vidal and Juliá-Igual, 2001, p. 67). He promulgated a new law on cooperatives in 1942: the Law of Cooperatives of the New State ('Ley de Cooperativas del Nuevo Estado'). The aim of this law was to keep ideological 'purity' through strict control. For instance, the Spanish State had the right to veto democratic decisions of the cooperative at any time (Marí-Vidal and Juliá-Igual, 2001, p. 66). When the dictator passed away in 1975, a representative democracy was restored with full political rights. New rules were promulgated in 1978 for cooperatives: Cooperative Firms Regulations ('Reglamento sobre Sociedades Cooperativas'). With the new rules, cooperative members recovered some rights: selfdetermination and the right to be informed (Marí-Vidal and Juliá-Igual, 2001, p. 68).

Two clear economic periods may also be identified: (1) economic liberalism as a consequence of the demand to belong to the European Union (EU); and (2) the European Union period from 1986, when Spain was integrated into the EU with complete economic rights.

\section{THEORETICAL BAGKGROUND}

\section{Environmental Variability}

Inter-organizational linkages are one important means for protecting an organization from environmental variability (Aldrich, 1979; Dickson and Weaver, 1997; DiMaggio and Powell, 1983). One of the main aims of inter-organizational linkages is to ensure the stable flow of critical resources (Pennings, 1981; Pfeffer and Salancik, 1978). An organization may form alliances with other organizations that can supply fundamental resources (Wright and Lockett, 2003). If insulation from the environment means protection from organizational failure, then organizations with inter-organizational linkages should have a lower mortality rate (Baum and Oliver, 1991; Ingram and Baum, 1997; Miner et al., 1990; Oliver, 1991; Stearns et al., 1987).

In this sense, the cooperative's suppliers form the ownership structure. That is to say, cooperative owners have a double role as member and supplier. This implies that the cooperative, through its ownership structure, has internalized the linkages with the suppliers that provide it with most of the critical resources to survive: the olive. Members participate in the organization as suppliers and, consequently, have greater identity with and commitment towards it (Bonin et al., 1993; Locke and

This is the pre-peer-reviewed version of the following article: Journal of Management Studies, vol.41, n.7, p.1131-1152, 
Schweiger, 1979). The cooperative philosophy is based on mutual aid and cooperation to enhance business viability (Staber, 1992, p. 1192). This implies that members have a vested interest in the success of their organization (Simons and Ingram, 2000). Moreover, it would be necessary that cooperative principles reaffirm this level of commitment by obliging members to participate in the cooperative's production process (International Cooperative Alliance, 1995). That is, the member has an exclusive and strong linkage with its cooperative, preventing any other outside activity. This implies that any cooperative, merely by its ownership structure, would have guaranteed the supply of resources by all of its supplier-members.

The ownership structure of other organizational forms is different and does not guarantee the same flow of resources in this natural way. Therefore, they need to obtain the same resources through greater effort. By combining these theoretical explanations, we formulate Hypothesis 1 as:

Hypothesis 1: Cooperatives are less likely to fail than firms integrated in other organizational forms.

Hypothesis 1 generally could be considered as a rule in the face of ordinary environmental fluctuations. However, the environment could also suffer shock periods where there is high scarcity of resources. In these situations, linkages would be buffers to organizations since they continue supplying resources, while organizations without linkages will have more problems in acquiring them (Miner et al., 1990, pp. 691-2). Consequently, the cooperative form would suffer less from environmental shocks than other organizational forms because the contribution from its supplier-members is guaranteed. Other organizational forms will need to obtain resources through stronger competition.

The Spanish case is not an exception, and, as noted above, there were two shock periods where the environment was more aggressive. Firstly, during the post civilwar period as a consequence of the deep economic depression, and secondly, during the European Union period because elimination of tariff protection imposed stronger competition with firms in the rest of Europe.

If competition is directly and positively related to the probability of failure (Hannan and Freeman, 1977, 1989), then it is possible to foresee a link between shock periods and the probability of organizational death, as stated in Hypothesis 2:

Hypothesis 2: Cooperatives are less likely to fail in the presence of shock periods than are firms integrated in other organizational forms.

The ownership structure of the cooperative has another fundamental characteristic that affects another kind of linkage: it builds a direct participatory democracy

This is the pre-peer-reviewed version of the following article: Journal of Management Studies, vol.41, n.7, p.1131-1152, which has been published in final form at http://dx.doi.org/10.1111/j.1467-6486.2004.00469.x 
in its government structure (Rothschild and Whitt, 1989). This attribute by itself could generate several problems: (1) it hinders internal hierarchy or strategic leadership, which is a fundamental organizational characteristic for obtaining efficiency (Williamson, 1987); (2) it creates agency costs (Rao and Neilsen, 1992); and (3) it represents a rival ideology to some regimes (Ingram and Simons, 2000), especially dictatorships (Rothschild and Whitt, 1989, p. 168).

A fascist regime has multiple characteristics, but the important ones in this context are its rigid hierarchical government structure, similar to an ordinary corporation in a capitalist economy, and its ideology. On the other hand, the structure and the intellectual background of any cooperative are democratic (Rothschild and Whitt, 1989, p. 13).

As a general rule, organizations adopt institutionally prescribed characteristics. Moreover, institutional pressures oblige structural similarities or isomorphism across organizations during a period of nationalism (Dacin, 1997, p. 72). This isomorphic pressure can be particularly severe when an organization's ideology is opposed to the environment, since the incentives will favour organizational practices that are consistent with the environmental ideology (Dobrev, 2001; Simons and Ingram, 1997). The State struggles to use its coercive capacity for its own ideological purposes (Wade et al., 1998). Therefore, the State could penalize organizations with different ideologies in several dimensions (Ingram and Simons, 2000). In this sense, it seems logical to think that a fascist regime, which has violently overthrown a government because of all the 'problems' arising from its democratic condition, will also try to remove organizations representative of the democracy. Therefore, we formulate Hypothesis 3 as:

Hypothesis 3: Cooperatives are more likely to fail in the presence of a fascist regime than are firms integrated in other organizational forms.

\section{Competition Among Organizational Forms}

By using Hutchinson's terminology (1957), the fundamental niche of an organizational form is the n-dimensional resource space that can sustain the functioning of organizations that embody the form. When the fundamental niches of two organizational forms coincide, then it is necessary to bear in mind the realized niche of each organizational form. That is to say, the realized niche is the available n-dimensional resource space of an organizational form when competitors are present (Hannan and Freeman, 1989).

As mentioned above, it is implied that the ownership structure either has or does not have linkages and, therefore, has or does not have access to fundamental resources. The cooperative form can exclude other forms from its fundamental niche because its members only facilitate their resources to itself. That is to say, it can isolate itself from other competitor forms and reduce them to their realized

This is the pre-peer-reviewed version of the following article: Journal of Management Studies, vol.41, n.7, p.1131-1152, 
niche. However, other organizational forms cannot do the same in relation to the cooperative. In this way, an organizational form (the cooperative, in our case) that can reduce the realized niche of other organizational forms is a stronger competitor (Hannan and Carroll, 1992, pp. 28-9). If we understand organizational strength as the competitive effect on the survival rate (Barnett, 1997), then we can enunciate Hypothesis 4 as:

Hypothesis 4: The larger realized niche of the cooperative form implies that firms integrated in other organizational forms are more likely to fail.

Since other organizational forms do not have ability to reduce the realized niche of the cooperative form because these have guaranteed their supply of resources, they will be weak competitors in reference to the cooperative form. Therefore, Hypothesis 5 would be:

Hypothesis 5: A larger realized niche of other organizational forms does not imply that firms integrated in the cooperative form are more likely to fail.

Lastly, the aim of cooperatives is to obtain resources, but their strategic advantage is to get them through their members. In this way, one could imagine that the real unit by which the cooperatives compete is the member, not the resources. In this sense, the only real competitors for cooperatives are themselves.

Hypothesis 6: The larger realized niche of the cooperative form implies greater likelihood of failure for cooperatives.

\section{METHOD}

\section{Data}

To test these hypotheses, a database was built containing information on 1298 oil mills. These were all the oil mills that have operated in the province of Jaén (Spain) at some time during the period 1944-98. The database has been built from the following sources:

- Register of agricultural firms held at the provincial office in Jaén of the Agricultural and Fisheries Department (a department of the Andalusian Regional Government). This register is the main information source for the database since it allowed the information to be obtained by each 'almazara' through the temporal horizon of this work. The inscription in this register is fundamental because an olive mill cannot start its activity or modify the existing one without this legal requirement. From 1944 to date, the staff from this Register have been checking the

This is the pre-peer-reviewed version of the following article: Journal of Management Studies, vol.41, n.7, p.1131-1152, 
observed data for each olive mill annually 'in situ'. If data were contradictory, then the continuing activity of the oil mill could be refused. From this register, we have taken the following information for each variable: date of birth, date of disbandment (if applicable), milling capacity installed, organizational form, number of employees, type of production ownership, and level of technological development.

- Register of cooperatives held at the provincial office in Faén of the Trade and Industry Department (a department of the Andalusian Regional Government). The special characteristics and the different nature of cooperatives have caused strict control from the dictatorial government to the present time. A consequence of this control was the Register of Cooperatives. In this register, information that is more exhaustive may be found: managers' names, members' names, internal decisions concerning change of activity, etc. Since this register only facilitates information about cooperatives, its only utility in this paper is to test the reliability of the information in the Register of Agricultural Firms.

- Agricultural Statistics Yearbooks. These yearbooks contain the official statistical information published by the Ministry of Agriculture, Fisheries and Food (Ministerio de Agricultura, Pesca y Alimentación). From these yearbooks, we have taken the annual oil harvests in the province of Jaén.

- Ministerial Orders and Royal Decrees (Legislative Decrees in Franco's era). The Ministry of Industry and Energy publishes these legal instructions in the Official Gazette. They set the price of electricity by year in Spain during the complete period of analysis.

\section{Variables}

The dependent variable is:

- Firm failure. This is the dependent variable for the entire statistical test. The failure of an oil mill was considered to have occurred when it stopped operating, that is, when the oil mill failed as a collective actor, but not when its ownership or trade name changed. In these cases, there were no justifiable reasons to conclude that the whole organization was transformed. In fact, it could continue to use the same procedures and routines (Baum and Mezias, 1992; Ingram and Inman, 1996). There are 11 mergers that have been taken as disappearances in the years in which they occurred because they might be considered as the loss of an independent collective actor (an oil mill). Although the mergers could be a symptom of success, we have considered them by using the criterion of other similar papers (Boone et al., 2000; Hannan and Carroll, 1992; Hannan and Freeman, 1989). In any case, the effect on the results would be insignificant because of the low proportion of failures from mergers (Agarwal et al., 2002, p. 981).

This is the pre-peer-reviewed version of the following article: Journal of Management Studies, vol.41, n.7, p.1131-1152, 
Independent variables are:

- Cooperative form/other organizational forms. We have analysed this effect through two mechanisms: (1) by introducing a dummy variable which has a value of 1 when the oil mill was integrated in the cooperative form and a value of 0 otherwise (Barron et al., 1998; Rao and Neilsen, 1992); and (2) by using two different models for each organizational form. To get this information we separated the database into two groups.

- Cooperative realized niche. We have used as a proxy of the cooperative realized niche the milling capacities installed for all the cooperative oil mills (in million kilos). This is the subset of resources that the cooperative form might obtain in the presence of the other competitive forms. In this way, the cooperative realized niche would be the sum of individual sizes of all cooperatives of this population.

- Capitalist realized niche. This is approximated by the mass of other organizational forms. The temporal evolution of these two variables in our data in particular may be seen in Figure 2.

- Dictatorship/democracy. We have analysed the influence of ideological periods (Miner et al., 1990) through two mechanisms: (1) by introducing a dummy variable which takes the value of 1 for the period 1939-75, and the value of 0 for the democratic period; and (2) by using two different models for each ideological period.

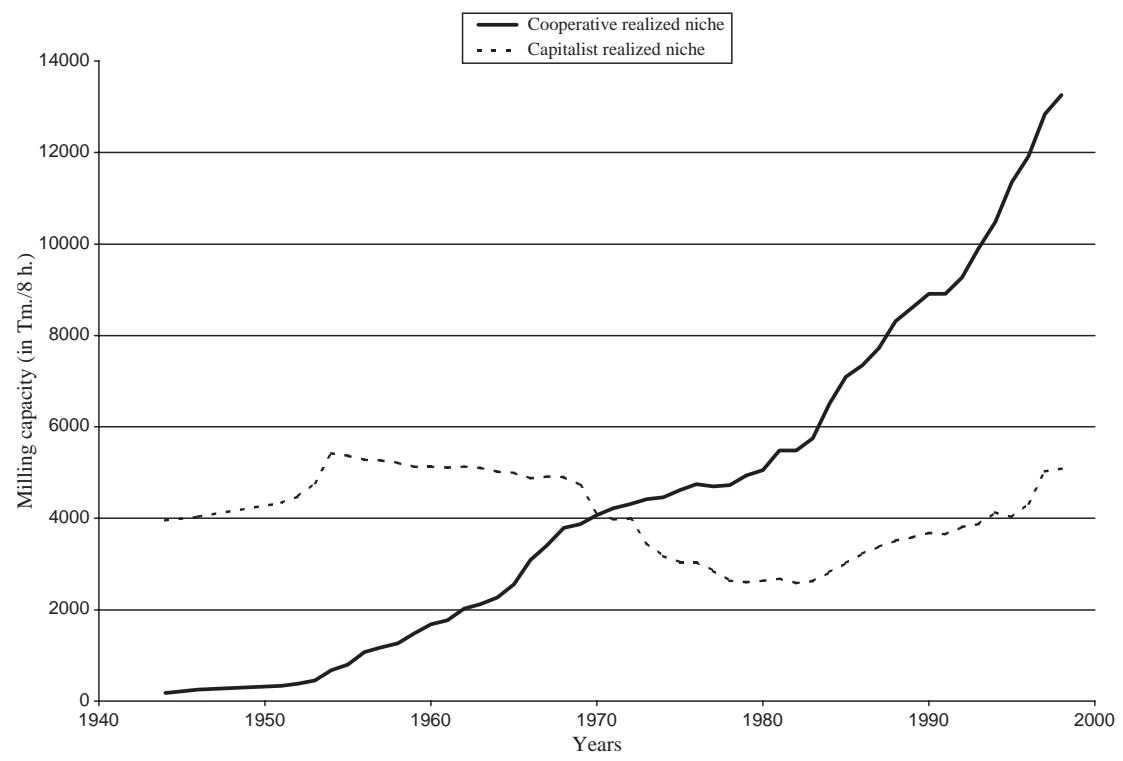

Figure 2. Cooperative realized niche and capitalist realized niche, 1944-1998

This is the pre-peer-reviewed version of the following article: Journal of Management Studies, vol.41, n.7, p.1131-1152, which has been published in final form at http://dx.doi.org/10.1111/j.1467-6486.2004.00469.x 
- The effect of the economic shocks has been included through two dummy variables: postwar and European Union periods. Both variables respectively take the value 1 between 1944 to 1959 , and 1986 to the present time, and the value 0 otherwise (Dacin, 1997; Staber, 1992).

Control variables are:

- Organizational age. This variable was defined as the number of years since the date of an oil mill's founding and its disbanding, or the end of the study period (1998). It is necessary as a control variable to overcome the left truncated data in studies of organizational mortality (Carroll and Hannan, 2000). To control for age dependence in mortality we used eight age-defined period dummy variables.

- Fundamental niche. Annual olive harvests (in million kilos) have been included to measure the fundamental niche since the olive might be considered the main resource in this industry.

- Type of production ownership. Boone et al. (2000) discovered that whether production ownership fell on one or various owners affects the probability of organizational failure. For this reason, a dummy variable was created that tells us if the oil mill is operated by the owner (value 1) or if it is operated under lease (value 0).

- Organizational size. We have identified the number of workers as the variable representing the size of each oil mill (Boone et al., 2000; Wholey and Brittain, 1989).

- Technological development. It has been demonstrated that technological development influences the probability of survival (Barnett, 1997; Baum et al., 1995). We have approximated this effect by the installed power in the motor set of each organization divided by its worker number.

- Electric energy cost. Electric energy is the power source that supplies the production system of an oil mill. This variable takes into account the cost of this supply in Pesetas per kWh and expresses the variable unit cost derived from the consumption of electric power. Moreover, apart from the raw material (olives), we could say that it is the main cost in an 'almazara'. This variable has been introduced following the approach in other papers of estimating vital rates to monitor the incidence of the main organization costs (Barnett and Carroll, 1987; Mascarenhas, 1996). Another possible cost could be labour costs. However, as noted above, a specialized work force is not required and, consequently, its cost is irrelevant in relation to energy cost. Nevertheless, technological development could be considered a proxy of this relationship.

- Population density. This variable allows controlling of one source of intrapopulation competition. In the density dependence model (Hannan, 1989), the intensity of competition varies according to the number of organizations

This is the pre-peer-reviewed version of the following article: Journal of Management Studies, vol.41, n.7, p.1131-1152, which has been published in final form at http://dx.doi.org/10.1111/j.1467-6486.2004.00469.x 


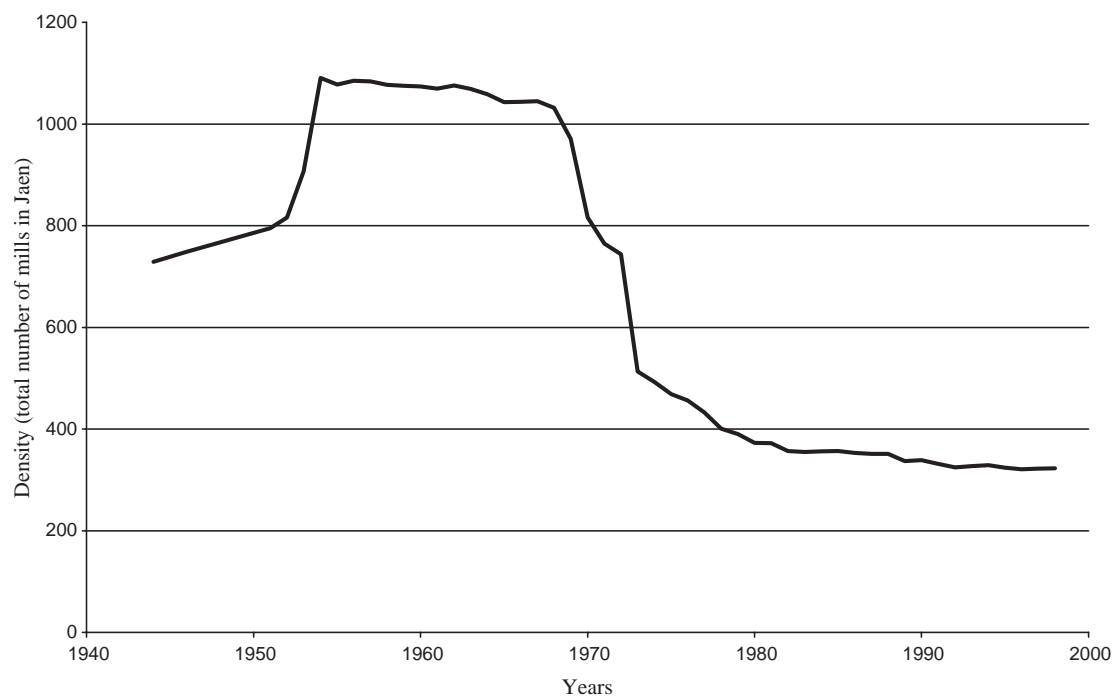

Figure 3. Evolution of number of olive oil mills 1944-1998

in a population. Population density was measured as the total number of oil mills existing at the start of each year. The density evolution against year for our population may be seen in Figure 3.

- Concentration. Since trends in density often roughly coincide with those of concentration (Hannan and Carroll, 1992, p. 48), we have also decided to include this variable (Figure 4). We assess the degree of concentration by the Herfindahl index (Barnett and Carroll, 1987; Wholey et al., 1992).

\section{Analysis}

To carry out the necessary tests, we have used the piecewise-exponential model with the following hazard rate:

$$
r(t)=e^{\beta x(t)}
$$

where $\beta$ is the associated vector of coefficients and $x$ the matrix of exogenous and control variables. The values of the different variables were introduced in oneyear increments. As noted above, this model allows a solution of the left-truncated data problem by including organizational age as a control variable (eight segments in our case), and using a calendar time as the dependent variable, which allows the instantaneous probability of failure, $r(t)$, to be estimated. These data have 114 as left-censored data and 487 as right-censored data. To overcome this data characteristic, maximum partial likelihood estimation was necessary (Cox and Oakes,

This is the pre-peer-reviewed version of the following article: Journal of Management Studies, vol.41, n.7, p.1131-1152, 


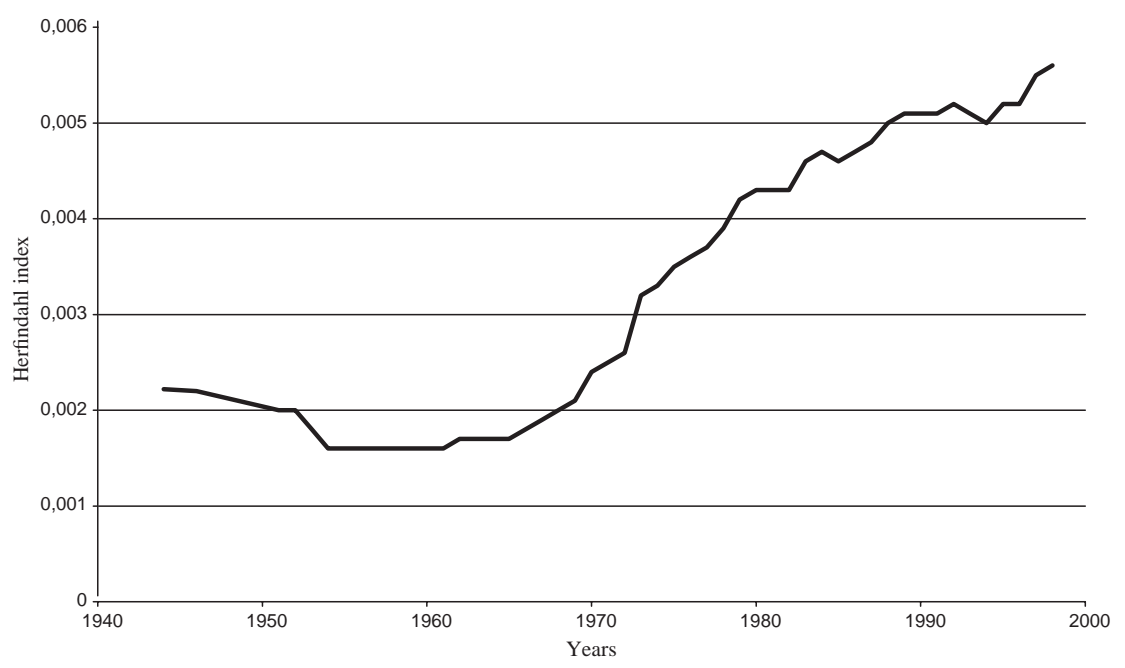

Figure 4. Concentration levels in Jaen's oil milling industry, 1944-1998

1984; Lawless, 1982). Following this methodology, we used the statistical package Stata 6.0 (Stata Corporation, 1999) to estimate the $\beta$ parameters. If $\beta$ has a positive sign, the organization's failure probability will increase. Alternatively, if the sign is negative this probability will be reduced.

\section{RESULTS}

Table I shows basic statistics and correlations between the independent variables and the control variables.

Table II shows the models built to test the influence of the independent variables on the probability of organizational failure. The first model is made using the total population database. The sample has been divided into two periods (dictatorship and democracy) to make the second and third models. We have also divided the total database in two: cooperative form, and other capitalist forms (Models 4 and 5). Lastly, we have built four more models: one for each period and for each organizational form. In this way, we might analyse influences through independent variables, and in an individual form for each period and organizational form.

Model 1 shows that the organizations making up the cooperative form benefit from more guarantees of survival. The coefficient of cooperative form has a negative and significant sign $(\mathrm{p}<0.0001)$. This circumstance is independently maintained in spite of the ideological movement in society (Models 2 and 3), and suggests that Hypothesis 1 can be accepted. The fact that owner and supplier coincide in the same person in the cooperative, together with the exclusive and strong

This is the pre-peer-reviewed version of the following article: Journal of Management Studies, vol.41, n.7, p.1131-1152, which has been published in final form at http://dx.doi.org/10.1111/j.1467-6486.2004.00469.x 
Table I. Basic statistics and correlations

\begin{tabular}{|c|c|c|c|c|c|c|c|c|c|c|c|c|c|c|c|}
\hline Variable & Mean & $S D$ & 1 & 2 & 3 & 4 & 5 & 6 & 7 & 8 & 9 & 10 & 11 & 12 & 13 \\
\hline $\begin{array}{l}\text { 1. Organizational } \\
\text { age }\end{array}$ & 37.26 & 23.92 & & & & & & & & & & & & & \\
\hline $\begin{array}{l}\text { 2. Cooperative } \\
\text { form }\end{array}$ & 0.309 & 0.462 & 0.036 & & & & & & & & & & & & \\
\hline 3. Postwar period & 0.371 & 0.483 & -0.240 & -0.366 & & & & & & & & & & & \\
\hline $\begin{array}{l}\text { 4. European } \\
\text { Union period }\end{array}$ & 0.140 & 0.347 & 0.203 & 0.266 & -0.311 & & & & & & & & & & \\
\hline $\begin{array}{l}\text { 5. Dictatorship/ } \\
\text { democracy }\end{array}$ & 0.727 & 0.445 & -0.249 & -0.377 & 0.470 & -0.661 & & & & & & & & & \\
\hline $\begin{array}{l}\text { 6. Fundamental } \\
\text { niche }\end{array}$ & 659.73 & 404.85 & 0.197 & 0.280 & -0.379 & 0.632 & -0.623 & & & & & & & & \\
\hline $\begin{array}{l}\text { 7. Cooperative } \\
\text { realized niche }\end{array}$ & 0.460 & 0.422 & 0.291 & 0.418 & -0.691 & 0.801 & -0.816 & 0.719 & & & & & & & \\
\hline $\begin{array}{l}\text { 8. Capitalist } \\
\text { realized niche }\end{array}$ & 0.568 & 0.139 & -0.104 & -0.188 & 0.191 & -0.133 & 0.513 & -0.194 & -0.296 & & & & & & \\
\hline $\begin{array}{l}\text { 10. Organizational } \\
\text { size }\end{array}$ & 11.71 & 11.12 & 0.025 & 0.342 & -0.156 & 0.053 & -0.144 & 0.086 & 0.144 & -0.124 & 0.110 & & & & \\
\hline $\begin{array}{l}\text { 11. Technological } \\
\text { development }\end{array}$ & 60.61 & 90.99 & 0.116 & 0.263 & -0.286 & 0.659 & -0.561 & 0.528 & 0.667 & -0.146 & 0.067 & -0.069 & & & \\
\hline $\begin{array}{l}\text { 12. Electric energy } \\
\text { cost }\end{array}$ & 30.22 & 40.38 & 0.259 & 0.359 & -0.465 & 0.878 & -0.862 & 0.663 & 0.911 & -0.324 & 0.068 & 0.105 & 0.687 & & \\
\hline 13. Density & 754.51 & 295.74 & -0.231 & -0.349 & 0.425 & -0.578 & 0.829 & -0.571 & -0.760 & 0.730 & -0.096 & -0.161 & -0.499 & -0.758 & \\
\hline 14. Concentration & 0.002 & 0.001 & 0.267 & 0.398 & -0.534 & 0.733 & -0.916 & 0.675 & 0.905 & -0.577 & 0.078 & 0.158 & 0.611 & 0.903 & -0.948 \\
\hline
\end{tabular}

Correlations $\geq|0.01|$ are significant at $\mathrm{p}<0.00001$.

This is the pre-peer-reviewed version of the following article:

Journal of Management Studies, vol.41, n.7, p.1131-1152,

which has been published in final form at http://dx.doi.org/10.1111/j.1467-6486.2004.00469.x 
linkage on the part of the members, supposes a guarantee of the supply of the resources that these organizations need for their operations.

Model 1 shows an unexpected result: a negative and significant influence of the economic recession (postwar period) on the probability of failure for the population as a whole. However, if we analyse this influence through Models 6, 7, 8 and 9 (specific models by period and organizational form) we see that this result is spurious. Shock periods (postwar period and European Union period) in any case, do not influence the cooperatives' probability of failure. However, these same periods do influence the probability of failure of other organizational forms with a high degree of significance. With these results, we accept Hypothesis 2.

Model 1 appears to indicate that the dictatorship period could benefit all organizational forms. However, when we analyse Models 4 and 5, we see a similar result to Hypothesis 2. The dictatorship period does not have a significant influence on the cooperatives' probability of failure but it does have a significant effect on the probability of failure of other organizational forms: negative in this case. Therefore, we can accept Hypothesis 3, since the fascist regime benefited other organizational forms more than cooperatives, in spite of the fact that cooperatives performed well to avoid this harmful influence.

In relation to the competition between organizational forms, the positive and significant sign of the cooperative realized niche parameter during the total period (Model 5), and for each period in particular (Models 8 and 9), points to support for Hypothesis 4. However, the inverse of the hypothesis is not supported. Larger realized niches of the ordinary capitalist form do not imply greater likelihood of failure for firms integrated in the cooperative form. Therefore, the total absence of significance in the parameters of the capitalist realized niche in Models 4, 6 and 7 support Hypothesis 5 with a high degree of significance. Cooperatives are stronger competitors than other organizational forms.

Finally, we have also tested the influence of competition of cooperatives on themselves. However, the results are not so clear. In spite of Model 4, which shows a positive influence of the cooperative realized niche on the probability of failure of cooperatives for the total period, an exhaustive analysis of this effect by period shows that this effect is produced only during the dictatorship period (Model 6). During the democracy period (Model 7), there is not a significant influence. Therefore, Hypothesis 6 cannot be supported. These results suggest that cooperative isolation is effective until the environment is so adverse that it forces them to compete between themselves for new resources: members.

There are some significant influences of control variables on mortality rates in the olive oil production industry. Technological development is a characteristic that always assists survival. The most developed technology implies the least probability of failure in any model.

Type of production ownership affects the probability of failure, but only in the cooperative form (Models 4, 6 and 7). When the owner operates the cooperative,

This is the pre-peer-reviewed version of the following article: Journal of Management Studies, vol.41, n.7, p.1131-1152, which has been published in final form at http://dx.doi.org/10.1111/j.1467-6486.2004.00469.x 
Table II. Piecewise exponential models of oil mill failure, 1944-98a

\begin{tabular}{|c|c|c|c|c|c|c|c|c|c|}
\hline $\begin{array}{l}\text { Period } \\
\text { Organizational form }\end{array}$ & $\begin{array}{l}\text { Total } \\
\text { Total } \\
\text { population }\end{array}$ & $\begin{array}{l}\text { Dictatorship } \\
\text { Total } \\
\text { population }\end{array}$ & $\begin{array}{l}\text { Democracy } \\
\text { Total } \\
\text { population }\end{array}$ & $\begin{array}{l}\text { Total } \\
\text { Cooperative }\end{array}$ & $\begin{array}{l}\text { Total } \\
\text { Other }\end{array}$ & $\begin{array}{l}\text { Dictatorship } \\
\text { Cooperative }\end{array}$ & $\begin{array}{l}\text { Democracy } \\
\text { Cooperative }\end{array}$ & $\begin{array}{l}\text { Dictatorship } \\
\text { Other }\end{array}$ & $\begin{array}{l}\text { Democracy } \\
\text { Other }\end{array}$ \\
\hline Variable & Model 1 & Model 2 & Model 3 & Model 4 & Model 5 & Model 6 & Model 7 & Model 8 & Model 9 \\
\hline \multicolumn{10}{|l|}{ Age periods } \\
\hline $0-2$ years & $\begin{array}{c}13.26 \\
(558.52)\end{array}$ & $\begin{array}{c}13.93 \\
(837.23)\end{array}$ & $\begin{array}{r}0.422 \\
(1108.95)\end{array}$ & $\begin{array}{c}-11.43 \\
(2405.21)\end{array}$ & $\begin{array}{c}13.61 \\
(660.38)\end{array}$ & $\begin{array}{c}-11.41 \\
(2425.51)\end{array}$ & $\begin{array}{r}0.537 \\
(2014.85)\end{array}$ & $\begin{array}{c}13.02 \\
(497.81)\end{array}$ & $\begin{array}{l}0.419 \\
-\end{array}$ \\
\hline $2-5$ years & $\begin{array}{c}-0.612 \\
(0.339)\end{array}$ & $\begin{array}{c}-0.626 \\
(0.339)\end{array}$ & $\begin{array}{c}-14.90 \\
-\end{array}$ & $\begin{array}{c}12.33 \\
(1157.95)\end{array}$ & $\begin{array}{c}-0.731^{*} \\
(0.356)\end{array}$ & $\begin{array}{c}12.34 \\
(1167.34)\end{array}$ & $\begin{array}{c}-14.62 \\
-\end{array}$ & $\begin{array}{c}-0.768^{*} \\
(0.361)\end{array}$ & $\begin{array}{c}-15.56 \\
-\end{array}$ \\
\hline $5-10$ years & $\begin{array}{l}0.283 \\
(0.160)\end{array}$ & $\begin{array}{l}0.275 \\
(0.160)\end{array}$ & $\begin{array}{c}11.82 \\
(443.57)\end{array}$ & $\begin{array}{c}0.008 \\
(0.374)\end{array}$ & $\begin{array}{l}0.322 \\
(0.176)\end{array}$ & $\begin{array}{c}-0.154 \\
(0.392)\end{array}$ & $\begin{array}{c}11.47 \\
(805.93)\end{array}$ & $\begin{array}{l}0.339 \\
(0.176)\end{array}$ & $\begin{array}{c}12.32 \\
(513.42)\end{array}$ \\
\hline $10-20$ years & $\begin{array}{l}0.048 \\
(0.034)\end{array}$ & $\begin{array}{l}0.035 \\
(0.039)\end{array}$ & $\begin{array}{c}0.034 \\
(0.087)\end{array}$ & $\begin{array}{l}0.176 \\
(0.096)\end{array}$ & $\begin{array}{l}0.024 \\
(0.036)\end{array}$ & $\begin{array}{l}0.268 \\
(0.121)\end{array}$ & $\begin{array}{c}0.065 \\
(0.189)\end{array}$ & $\begin{array}{l}0.002 \\
(0.042)\end{array}$ & $\begin{array}{c}0.022 \\
(0.099)\end{array}$ \\
\hline 20-30 years & $\begin{array}{l}-0.035 \\
(0.027)\end{array}$ & $\begin{array}{c}-0.043 \\
(0.031)\end{array}$ & $\begin{array}{l}0.005 \\
(0.055)\end{array}$ & $\begin{array}{c}-0.151 \\
(0.080)\end{array}$ & $\begin{array}{c}-0.028 \\
(0.028)\end{array}$ & $\begin{array}{c}-0.237 \\
(0.124)\end{array}$ & $\begin{array}{c}-0.024 \\
(0.121)\end{array}$ & $\begin{array}{c}-0.026 \\
(0.033)\end{array}$ & $\begin{array}{l}0.0004 \\
(0.063)\end{array}$ \\
\hline $30-40$ years & $\begin{array}{l}0.030 \\
(0.026)\end{array}$ & $\begin{array}{l}0.018 \\
(0.031)\end{array}$ & $\begin{array}{l}0.074 \\
(0.046)\end{array}$ & $\begin{array}{l}0.068 \\
(0.855)\end{array}$ & $\begin{array}{c}0.031 \\
(0.027)\end{array}$ & $\begin{array}{r}-0.079 \\
(0.164)\end{array}$ & $\begin{array}{c}0.125 \\
(0.103)\end{array}$ & $\begin{array}{c}0.022 \\
(0.032)\end{array}$ & $\begin{array}{c}0.060 \\
(0.052)\end{array}$ \\
\hline $40-50$ years & $\begin{array}{c}-0.0003 \\
(0.020)\end{array}$ & $\begin{array}{c}-0.001 \\
(0.026)\end{array}$ & $\begin{array}{r}-0.028 \\
(0.033)\end{array}$ & $\begin{array}{l}0.075 \\
(0.060)\end{array}$ & $\begin{array}{c}-0.009 \\
(0.023)\end{array}$ & $\begin{array}{l}0.186 \\
(136)\end{array}$ & $\begin{array}{c}0.029 \\
(0.070)\end{array}$ & $\begin{array}{r}-0.009 \\
(0.028)\end{array}$ & $\begin{array}{r}-0.039 \\
(0.039)\end{array}$ \\
\hline $50+$ years & $\begin{array}{l}0.001 \\
(0.005)\end{array}$ & $\begin{array}{l}0.009 \\
(0.007)\end{array}$ & $\begin{array}{c}-0.0009 \\
(0.007)\end{array}$ & $\begin{array}{c}-0.003 \\
(0.011)\end{array}$ & $\begin{array}{l}0.001 \\
(0.005)\end{array}$ & $\begin{array}{c}0.016 \\
(0.31)\end{array}$ & $\begin{array}{c}-0.010 \\
(0.012)\end{array}$ & $\begin{array}{l}0.008 \\
(0.007)\end{array}$ & $\begin{array}{c}0.002 \\
(0.009)\end{array}$ \\
\hline $\begin{array}{c}\text { Cooperative form/other } \\
\text { organizational forms }\end{array}$ & $\begin{array}{l}-0.755^{* * * *} \\
(0.134)\end{array}$ & $\begin{array}{l}-0.818^{* * * * *} \\
(0.197)\end{array}$ & $\begin{array}{l}-0.722^{* * * * *} \\
(0.192)\end{array}$ & & & & & & \\
\hline Postwar period & $\begin{array}{l}-0.902 * * * \\
(0.263)\end{array}$ & $\begin{array}{l}1.53 * * * * * \\
(0.399)\end{array}$ & & $\begin{array}{c}-0.151 \\
(0.896)\end{array}$ & $\begin{array}{c}-0.576 \\
(0.319)\end{array}$ & $\begin{array}{c}1.34 \\
(1.18)\end{array}$ & & $\begin{array}{l}1.76 \text { ***** } \\
(0.441)\end{array}$ & \\
\hline European Union period & $\begin{array}{l}0.017 \\
(0.362)\end{array}$ & & $\begin{array}{l}2.54 * * * * * \\
(0.729)\end{array}$ & $\begin{array}{l}0.680 \\
(0.745)\end{array}$ & $\begin{array}{l}0.040 \\
(0.476)\end{array}$ & & $\begin{array}{c}1.44 \\
(1.20)\end{array}$ & & $\begin{array}{l}3.12 * * * \\
(0.945)\end{array}$ \\
\hline Dictatorship/democracy & $\begin{array}{c}-1.55^{* * * * *} \\
(0.337)\end{array}$ & & & $\begin{array}{c}-1.55 \\
(1.08)\end{array}$ & $\begin{array}{r}-1.15^{* *} \\
(0.397)\end{array}$ & & & & \\
\hline
\end{tabular}

This is the pre-peer-reviewed version of the following article:

Journal of Management Studies, vol.41, n.7, p.1131-1152,

which has been published in final form at http://dx.doi.org/10.1111/j.1467-6486.2004.00469.x 


\begin{tabular}{|c|c|c|c|c|c|c|c|c|c|}
\hline Cooperative realized niche & $\begin{array}{l}5.94^{* * * * *} \\
(6.41)\end{array}$ & $\begin{array}{l}11.77 * * * * * \\
(1.18)\end{array}$ & $\begin{array}{l}10.95^{* *} \\
(4.01)\end{array}$ & $\begin{array}{l}5.39 * * \\
(2.06)\end{array}$ & $\begin{array}{l}6.92^{* * * * *} \\
(0.812)\end{array}$ & $\begin{array}{l}10.28^{* *} \\
(3.78)\end{array}$ & $\begin{array}{l}5.71 \\
(6.31)\end{array}$ & $\begin{array}{l}12.43 * * * * * \\
(1.30)\end{array}$ & $\begin{array}{l}13.58^{* *} \\
(5.20)\end{array}$ \\
\hline Capitalist realized niche & $\begin{array}{r}-2.52^{* *} \\
(0.859)\end{array}$ & $\begin{array}{c}-0.881 \\
(1.65)\end{array}$ & $\begin{array}{l}-31.09 * * \\
(11.19)\end{array}$ & $\begin{array}{r}-5.05 \\
(5.39)\end{array}$ & $\begin{array}{l}-4.98^{* *} \\
(1.91)\end{array}$ & $\begin{array}{l}3.24 \\
(7.37)\end{array}$ & $\begin{array}{r}-15.16 \\
(17.66)\end{array}$ & $\begin{array}{l}5.86^{* *} \\
(2.06)\end{array}$ & $\begin{array}{l}-40.82 * * \\
(14.75)\end{array}$ \\
\hline Fundamental niche & $\begin{array}{l}0.0009 * * * * \\
(0.0001)\end{array}$ & $\begin{array}{r}-0.0001 \\
(0.0003)\end{array}$ & $\begin{array}{l}-0.001 * * * * * \\
(0.0003)\end{array}$ & $\begin{array}{r}-0.0007^{*} \\
(0.0003)\end{array}$ & $\begin{array}{l}0.0009^{* * * * *} \\
(0.0002)\end{array}$ & $\begin{array}{r}-0.0001 \\
(0.0009)\end{array}$ & $\begin{array}{l}-0.001 \\
(0.0005)\end{array}$ & $\begin{array}{r}-0.0005 \\
(0.0003)\end{array}$ & $\begin{array}{l}-0.001 \text { 1***** } \\
(0.0004)\end{array}$ \\
\hline $\begin{array}{l}\text { Type of production } \\
\text { ownership }\end{array}$ & $\begin{array}{c}-0.236^{*} \\
(0.103)\end{array}$ & $\begin{array}{r}-0.176 \\
(0.124)\end{array}$ & $\begin{array}{r}-0.260 \\
(0.186)\end{array}$ & $\begin{array}{c}-1.46 * * * * \\
(0.291)\end{array}$ & $\begin{array}{r}-0.127 \\
(0.110)\end{array}$ & $\begin{array}{r}-1.16^{* *} \\
(0.393)\end{array}$ & $\begin{array}{r}-1.35^{*} \\
(0.472)\end{array}$ & $\begin{array}{c}-0.052 \\
(0.132)\end{array}$ & $\begin{array}{r}-0.133 \\
(0.200)\end{array}$ \\
\hline Organizational size & $\begin{array}{l}-0.095^{* * * * * *} \\
(0.010)\end{array}$ & $\begin{array}{l}-0.151^{* * * * *} \\
(0.017)\end{array}$ & $\begin{array}{l}-0.053^{* * * * * *} \\
(0.012)\end{array}$ & $\begin{array}{l}-0.056^{* * * *} \\
(0.016)\end{array}$ & $\begin{array}{l}-0.100^{* * * * * *} \\
(0.012)\end{array}$ & $\begin{array}{l}-0.160^{\text {****** }} \\
(0.044)\end{array}$ & $\begin{array}{r}-0.030 \\
(0.017)\end{array}$ & $\begin{array}{l}-0.144^{* * * * *} \\
(0.018)\end{array}$ & $\begin{array}{l}-0.057^{* * * * *} \\
(0.016)\end{array}$ \\
\hline Technological development & $\begin{array}{l}-0.154^{* * * * *} \\
(0.016)\end{array}$ & $\begin{array}{l}-0.224 * * * * \\
(0.035)\end{array}$ & $\begin{array}{l}-0.122^{* * * * *} \\
(0.018)\end{array}$ & $\begin{array}{l}-0.149 * * * * \\
(0.030)\end{array}$ & $\begin{array}{l}-0.155^{\text {***** }} \\
(0.019)\end{array}$ & $\begin{array}{c}-0.259 * \\
(0.126)\end{array}$ & $\begin{array}{l}-0.141^{* * * * *} \\
(0.032)\end{array}$ & $\begin{array}{l}-0.220^{* * * * *} \\
(0.036)\end{array}$ & $\begin{array}{l}-0.111 \text { ***** } \\
(0.022)\end{array}$ \\
\hline Electric energy cost & $\begin{array}{l}-0.248 * * * * * \\
(0.044)\end{array}$ & $\begin{array}{r}-0.676 \\
(0.487)\end{array}$ & $\begin{array}{r}-0.083 \\
(0.129)\end{array}$ & $\begin{array}{c}-0.034 \\
(0.100)\end{array}$ & $\begin{array}{l}-0.327^{\text {****** }} \\
(0.053)\end{array}$ & $\begin{array}{l}-1.37 \\
(1.65)\end{array}$ & $\begin{array}{l}0.138 \\
(0.246)\end{array}$ & $\begin{array}{c}-0.354 \\
(0.296)\end{array}$ & $\begin{array}{c}-0.159 \\
(0.154)\end{array}$ \\
\hline Density & $\begin{array}{c}-0.001 \\
(0.001)\end{array}$ & $\begin{array}{l}0.005^{*} \\
(0.002)\end{array}$ & $\begin{array}{c}0.026 \\
(0.014)\end{array}$ & $\begin{array}{c}-0.0008 \\
(0.003)\end{array}$ & $\begin{array}{l}0.0002 \\
(0.001)\end{array}$ & $\begin{array}{c}0.006 \\
(0.007)\end{array}$ & $\begin{array}{c}0.017 \\
(0.027)\end{array}$ & $\begin{array}{l}0.004^{*} \\
(0.002)\end{array}$ & $\begin{array}{c}0.033 \\
(0.017)\end{array}$ \\
\hline Concentration & $\begin{array}{c}-670.17 \\
(411.11)\end{array}$ & $\begin{array}{c}1593.18 \\
(1114.18)\end{array}$ & $\begin{array}{c}-2064.19 \\
(1151.96)\end{array}$ & $\begin{array}{r}-1704.63 \\
(931.59)\end{array}$ & $\begin{array}{c}-573.61 \\
(479.75)\end{array}$ & $\begin{array}{l}2356.91 \\
(3455.95)\end{array}$ & $\begin{array}{c}-1806.28 \\
(1862.63)\end{array}$ & $\begin{array}{c}2132.81^{*} \\
(1066.78)\end{array}$ & $\begin{array}{c}-2093.68 \\
(1502.61)\end{array}$ \\
\hline Chi-squared $\left(\chi^{2}\right)$ & $857.49 * * * *$ & $730.64 * * * *$ & $286.42^{* * * * *}$ & $137.26^{* * * * *}$ & $701.96^{* * * * *}$ & $87.68^{* * * * *}$ & $82.89 * * * * *$ & $658.95^{* * * *}$ & $156.19^{* * * * *}$ \\
\hline Degrees of freedom & 21 & 19 & 19 & 20 & 20 & 18 & 18 & 18 & 18 \\
\hline
\end{tabular}

$* * * * \mathrm{p}<0.0001 ; * * * \mathrm{p}<0.001 ; * * \mathrm{p}<0.01: * \mathrm{p}<0.05$.

${ }^{\mathrm{a}}$ Standard errors are in parentheses. 
it has less probability of failure. Another result is that increase in organizational size implies increase in the probability of survival. Only one model, among the nine, is not significant in its coefficient, although its sign is also negative.

There is no significant influence of density and concentration on the probability of failure of any organizational form. Electric energy cost also shows no significant effect. Thus, it is not possible to draw conclusions on the sign of these parameters.

\section{GONGLUSIONS}

Within the research line on cooperative form, there is a fundamental question without a clear answer: 'Does the cooperatives' unusual ownership and governance structure give them any advantage over their commercial rivals?' (Barron et al., 1998, p. 28). Depending on the authors and their focus, research results are diametrically opposed. In this work, we answer it in the affirmative.

This paper has been an attempt to show that the cooperative ownership structure might be seen as a strategy to form stronger linkages with suppliers and, hence, to obtain fundamental resources for survival. In a cooperative, the members are its suppliers. That is to say, cooperatives link themselves to their suppliers by including them in the ownership structure. Therefore, if this relationship were considered as an inter-organizational linkage (Baum and Oliver, 1991; Ingram and Baum, 1997; Oliver, 1991; Stearns et al., 1987), or an organizational buffer according to Miner et al. (1990), its effect would be to reduce the probability of failure. In our opinion, the results in this paper support this idea. The advantages of the Andalusian cooperatives go so far, but are cancelled by the typically hostile reaction of the fascist ideology to cooperatives. This result is interesting because it stresses the difference between the two definitions of legitimacy: cognitive and socio-political legitimacy (Baum, 1996, p. 88). The latter is understood to be the conformity of an organizational form to social and institutional expectations (DiMaggio and Powell, 1983). A form acquires constitutive legitimacy when there is little question in the minds of actors that it serves as the natural way to affect some kind of collective action (Hannan and Carroll, 1992, p. 34). That is to say, an organizational form gains legitimacy when it attains a socially taken-for-granted character (Meyer and Rowan, 1977). Our paper could be considered as a proof of this difference. The fascist socio-political legality did not cause failure of the cooperative form since the taken-for-granted legitimacy had a stronger influence. Although Franco's regime was legal because it promulgated laws, it is not so clear that these laws were legitimate in this second sense.

The cooperative's ownership structure is a buffer for other threats including environmental shocks or economic depressions. Cooperatives are also stronger competitors in relation to other organizational forms. They could be predators because they reduce the realized niche of other organizational forms. However,

This is the pre-peer-reviewed version of the following article: Journal of Management Studies, vol.41, n.7, p.1131-1152, which has been published in final form at http://dx.doi.org/10.1111/j.1467-6486.2004.00469.x 
other organizational forms cannot reduce the cooperatives' realized niche (Brittain, 1994; Swaminathan and Wiedenmayer, 1991). Consequently, cooperatives increase the probability of failure of other organizational forms although the other forms cannot affect them. We also think cooperatives change the competition scale. They compete by resources, but through their members. That is to say, they try to increase the number of members to obtain a larger quantity of resources. Cooperatives compete through legitimacy since more legitimacy implies a larger number of members and more resources for survival. However, this effect is not clear. We have only obtained evidence of this phenomenon in the dictatorship period.

An advantage of the Spanish olive oil milling industry is that it allows us to simplify the problem to one fundamental resource, the quantity of olives. This simplification makes it easy to achieve two linked conclusions: firstly, if the main and only resource is the olive, it is logical to think that an ownership structure that provides this resource will be more successful than other organizational forms. However, this is not the same as saying: 'all cooperatives are more successful'. We could think about other kinds of cooperatives that do not have this characteristic and, therefore, are not successful in this industry. For instance, we have not found a one-only worker or customer cooperative in this industry during the analysed period. We could conclude that this is a consequence of the work force and customers not being strategic resources in this sector although they could be in other industry sectors. The optimal cooperative form would be one that makes it easier to obtain the main resource from the environment.

Further, as noted above, if there exists only one important resource, and its influence on the other organizational forms is controlled by its realized niche's behaviour, it also seems logical to think that other variables are not significant. This could be the explanation for the lack of significance of two of the most important variables in population ecology: density and concentration. We are inclined to think that both density and concentration gather effects when there exist several and different important resources that cannot be individually controlled.

We have not proved that cooperatives are more efficient than other organizational forms in Williamson's sense (1987), but if survival were synonymous with efficacy, Andalusian cooperatives in the olive oil milling industry would be efficacious. If we add to this success factor their social characteristics of giving more consideration to people (the human factor has priority over the capital one), or their principles such as democracy, equality, equity, and solidarity, then, perhaps, cooperatives would be seen with other eyes. Maybe they are not anachronisms from other eras but a valid alternative to current economic instability or market concentration.

More work is necessary with other sorts of cooperatives in other industries. Although this population could be an exception, results from Barron et al. (1998) allow us to suppose that our findings are not an isolated and only case.

This is the pre-peer-reviewed version of the following article: Journal of Management Studies, vol.41, n.7, p.1131-1152, which has been published in final form at http://dx.doi.org/10.1111/j.1467-6486.2004.00469.x 


\section{NOTE}

*This research was funded by FEGA-FEOGA (CAO99-019) and by Ministerio de Ciencia y Tecnología (SEC2001-0657). We would like to thank three anonymous reviewers for their insightful comments on the earlier version of this paper.

\section{REFERENGES}

Agarwal, R., Sarkar, M. B. and Echambadi, R. (2002). 'The conditioning effect of time on firm survival: an industry life cycle approach'. Academy of Management fournal, 45, 971-94.

Aldrich, H. (1979). Organizations and Environments. Englewood Cliffs, NJ: Prentice-Hall.

Barnett, W. P. (1997). 'The dynamics of competitive intensity'. Administrative Science Quarterly, 42, $128-60$.

Barnett, W. P. and Carroll, G. R. (1987). 'Competition and mutualism among early telephone companies'. Administrative Science Quarterly, 32, 400-21.

Barron, D. N. (1995). 'Credit unions'. In Carroll, G. R. and Hannan, M. T. (Eds), Organizations in Industry. New York: Oxford University Press, 137-62.

Barron, D. N., West, E. and Hannan, M. T. (1998). 'Deregulation and competition in the financial industry'. Industrial and Corporate Change, 7, 1-32.

Baum, J. A. C. (1996). 'Organizational ecology'. In Clegg, S. R., Hardy, C. and Nord, W. R. (Eds), Handbook of Organization Studies. London: Sage, 77-114.

Baum, J. A. C. and Mezias, S. (1992). 'Localized competition and organizational failure in the Manhattan hotel industry, 1898-1990'. Administrative Science Quarterly, 37, 580-604.

Baum, J. A. C. and Oliver, C. (1991) 'Institutional linkages and organizational mortality'. Administrative Science Quarterly, 36, 187-218.

Baum, J. A. C., Korn, H. J. and Kotha, S. (1995). 'Dominant designs and population dynamics in telecommunications services: founding and failure of facsimile transmission service organizations, 1965-1992'. Social Science Research, 24, 97-135.

Ben-ner, A. (1988). 'Comparative empirical observations on worker-owned and capitalist firms'. International Fournal of Industrial Organization, 6, 7-31.

Ben-ner, A. and Jones, D. C. (1995). 'Employee participation, ownership and productivity: a theoretical framework'. Industrial Relations, 34, 532-54.

Bonin, J. P., Jones, D. C. and Putterman, L. (1993). 'Theoretical and empirical studies of producer cooperatives: will ever the twain meet?'. Journal of Economic Literature, 31, 1290-320.

Boone, C., Bröcheler, V. and Carroll, G. R. (2000). 'Custom service: application and tests of resourcepartitioning theory among Dutch auditing firms from 1896 to 1992'. Organization Studies, 21, 355-81.

Brittain, J. W. (1994). 'Density-independent selection and community evolution'. In Baum, J. A. G. and Singh, J. V. (Eds), Evolutionary Dynamics of Organizations. New York: Oxford University Press, $355-78$.

Carroll, G. R. and Hannan, M. T. (2000). The Demography of Corporations and Industries. Princeton, NJ: Princeton University Press.

Carroll, G. R., Goodstein, J. and Gyenes, A. (1988). 'Organizations and the state: effects on the institutional environment on agricultural cooperatives in Hungary'. Administrative Science Quarterly, 33, 233-56.

Cox, D. R. and Oakes, D. R. (1984). Analysis of Survival Data (Monographs on Statistics and Applied Probability). New York: Chapman and Hall.

Dacin, M. T. (1997). 'Isomorphism in context: the power and prescription of institutional norms'. Academy of Management fournal, 40, 46-81.

Dickson, P. H. and Weaver, K. M. (1997). 'Environmental determinants and individual-level moderators of alliance use'. Academy of Management Fournal, 40, 404-25.

DiMaggio, P. J. and Powell, W. W. (1983). 'The iron cage revisited: institutional isomorphism and collective rationality in organizational fields'. American Sociological Review, 48, 147-60.

Dobrev, S. D. (2001). 'Revisiting organizational legitimization cognitive diffusion and sociopolitical factors in the evolution of Bulgarian newspaper enterprises, 1846-1992'. Organization Studies, 22, 419-44.

This is the pre-peer-reviewed version of the following article: Journal of Management Studies, vol.41, n.7, p.1131-1152, which has been published in final form at http://dx.doi.org/10.1111/j.1467-6486.2004.00469.x 
Ernst \& Young Assessors (1992). Estudio sobre la Posición Competitiva del Sector de Alimentación y Bebidas en España. Sector de Aceite de Oliva y Aceite de Orujo de Aceituna. Madrid: Ministerio de Agricultura, Pesca y Alimentación.

Gutierrez-Johnson, A. and Whyte, W. F. (1977). 'The Mondragon system of worker production cooperatives'. Industrial and Labor Relations Review, 31, 18-30.

Hannan, M. T. (1989). 'Competitive and institutional processes in organizational ecology'. In Berger, J., Zelditch, M. and Andersen, B (Eds), Sociological Theories in Progress: New Formulations. Newbury Park, CA: Sage, 388-402.

Hannan, M. T. and Carroll, G. R. (1992). Dynamics of Organizational Populations: Density, Legitimation and Competition. New York: Oxford University Press.

Hannan, M. T. and Freeman, J. (1977). 'The population ecology of organizations'. American fournal of Sociology, 82, 929-64.

Hannan, M. T. and Freeman, J. (1989). Organizational Ecology. Cambridge, MA: Harvard University Press.

Hansmann, H. (2000). The Owenership of Enterprise. Cambridge, MA: Harvard University Press.

Hutchinson, G. E. (1957). 'Concluding remarks'. Cold Spring Harbor Symposium on Qualitative Biology, 22, 415-27.

Ingram, P. and Baum, J. A. C. (1997). 'Chain affiliation and the failure of Manhattan hotels, 1898-1980'. Administrative Science Quarterly, 42, 68-102.

Ingram, P. and Inman, C. (1996). 'Institutions, intergroup, competition, and the evolution of hotel populations around Niagara falls'. Administrative Science Quarterly, 41, 629-58.

Ingram, P. and Simons, T. (2000). 'State formation, ideological competition, and the ecology of Israeli workers' cooperatives, 1920-1992'. Administrative Science Quarterly, 45, 25-53.

International Cooperative Alliance (1995). Agenda and Reports, Summaries and Translations. Geneva: XXXIst Congress, Manchester 1995.

Lawless, J. F. (1982). Statistical Models and Methods for Lifetime Data. New York: Wiley and Sons.

Locke, E. A. and Schweiger, D. M. (1979). 'Participation in decision-making: one more look'. In Cummings, L. L. and Staw, B. M. (Eds), Research in Organizational Behavior. Greenwich: JAI Press, 265-339.

Mascarenhas, B. (1996). 'The founding of specialist firms in a global fragmenting industry'. Fournal of International Business Studies, 27, 27-42.

Marí-Vidal, S. and Juliá-Igual, J. F. (2001). 'Evolución del cooperativismo agrario en España. De los sindicatos agrícolas a la actualidad'. Revista de Estudios Cooperativos (Revesco), 73, 59-80.

Meyer, J. W. and Rowan, B. (1977). 'Institutionalized organizations: formal structure as myth and ceremony'. American fournal of Sociology, 83, 340-63.

Miner, A. S., Amburgey, T. L. and Stearns, T. M. (1990). 'Interorganizational linkages and population dynamics: buffering and transformational shields'. Administrative Science Quarterly, 35, 689-713.

Oliver, C. (1991). 'Strategic responses to institutional processes'. Academy of Management Review, 16, 145-79.

Pencavel, J. (2002). Worker Participation. New York: Russell Sage Foundation.

Pennings, J. M. (1981). 'Strategically interdependent organizations'. In Nystrom, P. and Starbuck, W. (Eds), Handbook of Organizational Design. New York: Oxford University Press, 433-55.

Pfeffer, J. and Salancik, G. R. (1978). The External Control of Organizations: A Resource Dependence Perspective. New York: Harper and Row.

Putterman, L. (1982). 'Some behavioral perspectives on the dominance of hierarchical over democratic forms of enterprise'. Fournal of Economic Behavior and Organization, 3, 139-60.

Ranger-Moore, J., Banaszak-Holl, J. and Hannan, M. T. (1991). 'Density-dependent dynamics in regulated industries: founding rates of banks and life insurance companies'. Administrative Science Quarterly, 36, 36-65.

Rao, H. and Neilsen, E. H. (1992). 'An ecology of agency arrangements: mortality of savings and loan associations, 1960-1987'. Administrative Science Quarterly, 37, 448-70.

Rothschild, J. and Whitt, J. A. (1989). The Cooperative Workplace. Cambridge, MA: Cambridge University Press.

Russell, R. (1985). 'Employee ownership and internal governance'. Fournal of Economic Behavior and Organization, 6, 217-41.

Simons, T. and Ingram, P. (1997). 'Organization and ideology: Kibbutzim and hired labor, 1951-1965'. Administrative Science Quarterly, 42, 784-813.

This is the pre-peer-reviewed version of the following article: Journal of Management Studies, vol.41, n.7, p.1131-1152, which has been published in final form at http://dx.doi.org/10.1111/j.1467-6486.2004.00469.x 
Simons, T. and Ingram, P. (2000). 'The Kibbutz for organizational behavior'. In Barry, S. and Sutton, R. (Eds), Research in Organizational Behavior. Greenwich: JAI Press, 283-344.

Staber, U. H. (1992). 'Organizational interdependence and organizational mortality in the cooperative sector: a community ecology perspective'. Human Relations, 45, 1191-212.

Stata Corporation (1999). Stata Statistical Software: Release 6.0. College Station, TX: Stata Press.

Stearns, T. M., Hoffman, A. N. and Heide, J. B. (1987). 'Performance of commercial television stations as an outcome of interorganizational linkages and environmental conditions'. Academy of Management fournal, 30, 71-90.

Swaminathan, A. and Wiedenmayer, G. (1991). 'Does the pattern of density-dependence in organizational mortality rates vary across levels of analysis? Evidence from the German Brewing Industry'. Social Science Research, 20, 45-73.

Torres, F. J. (1998). Las Cooperativas Fiennenses y la Comercialización de los Aceites de Oliva: Una Perspectiva Estratégica. Jaén: Instituto de Estudios Giennenses.

Tortella, G. (1994). El Desarrollo de la España Contemporánea. Historia Económica de los siglos XIX y XX. Madrid: Alianza Universidad.

Wade, J. B., Swaminathan, A. and Saxon, M. S. (1998). 'Normative and resource flow consequences of local regulations in the American brewing industry, 1845-1918'. Administrative Science Quarterly, 43, 905-35.

Wholey, D. R and Brittain, J. (1989). 'Characterizing environmental variation'. Academic of Management Fournal, 32, 867-82.

Wholey, D. R., Christianson, J. B. and Sanchez, S. M. (1992). 'Organizational size and failure among health maintenance organizations'. American Sociological Review, 57, 829-42.

Williamson, O. E. (1987) The Economic Institutions of Capitalism. New York: Free Press.

Wright, M. and Lockett, A. (2003). 'The structure and management of alliances: Syndication in the venture capital industry'. Fournal of Management Studies, 40, 8, 2073-102.

This is the pre-peer-reviewed version of the following article: Journal of Management Studies, vol.41, n.7, p.1131-1152, 